\title{
Leucistic South American sea lion in Chile, with a review of anomalously color in otariids
}

\author{
Registro en Chile de leucismo en lobo marino común, con una revisión de \\ las coloraciones anormales en otáridos \\ Jorge Acevedo $^{1}$ and Mauricio Aguayo ${ }^{2}$ \\ ${ }^{1}$ Centro de Estudios del Cuaternario (CEQUA). Avda. Bulnes 01890, Punta Arenas, Chile \\ ${ }^{2}$ Centro de Ciencias Ambientales EULA-Chile. Universidad de Concepción. Casilla 160-C. Concepción, Chile \\ jacevedo@inach.cl
}

\begin{abstract}
Resumen.- Las coloraciones anormales en los mamíferos marinos ocurren en muy baja frecuencia. Estas coloraciones atípicas son clasificadas como albinismo, melanismo y leucismo, siendo esta última coloración registrada con más frecuencia en Arctocephalus gazella. En este artículo se
\end{abstract}

documenta el primer caso de leucismo en un ejemplar de Otaria flavescens observado en la zona austral de Chile, así como de una actualización de coloraciones atípicas informadas en otáridos.

Key words: Otaria flavescens, leucism, atypical color

\section{Introduction}

Mammalian color is caused almost solely by the presence (or absence) of the pigment melanin in the skin, hair and eyes (Fertl \& Rosen 2002). Atypical color can sometimes occur due to an excess, or a deficiency, of color pigment in some or all the body. Such conditions have been categorised as: 'albinism', a complete lack of pigmentation in the feathers, eyes, skin and hair; 'leucism' characterized by reduced pigmentation that may appear virtually pure white but still possess normally colored eyes and skin; and 'melanism' that is an increased amount of black or nearly black pigmentation.

Atypical colorations occur in low frequency in marine mammals. In cetaceans atypical cases have been reported for 22 species (Fertl et al. 1999, 2004); while in pinnipeds are known to occur mainly in Antarctic fur seals (e.g. Bonner 1958, 1964, 1968) and in low frequency in seals (Bried \& Haubreux 2000, Bester et al. 2008). No reports are known in sea otters or sirenians (Fertl \& Rosel 2002). To our knowledge, neither leucism color have ever been observed in South American sea lion although very light coloured individuals have been recorded usually in this species. We present the first known account for a leucistic South American sea lion (Otaria flavescens Shaw, 1800), on southern Chile, as well as an update for this atypical coloring in otariids.

\section{Material and methods}

In February 2007, during an opportunistic cruise of five days in the Marine and Coast Protected Area (AMCP) 'Francisco Coloane' an atypical South American sea lion was sighted and photographed in a group of five conspecifics males and one South American fur seal (Arctocephalus australis Zimmermann, 1783), on the rookeries coast of Paso Shag (53¹9.84 S; $72^{\circ} 06.09$ W), near the Magellan Strait, Chile (Fig. 1).

\section{Results and discussion}

The animal, a subadult male, was uniformly creamy white in color on all pelage, while the flippers and adjacent zone was light brown, but the eyes and nose were normally pigmented (Fig. 2). Such pigmentation is similar to the color reported for leucistic individual of Antarctic fur seal (e.g. Bonner 1968, Cárdenas \& Yañez 1983). The group with the leucistic individual was resting and was sighted approximately $20 \mathrm{~m}$ from the vessel. This individual was observed for a total of $15 \mathrm{~min}$, however, on our return to the same place later in the day the animal was not seen again. An animal of such description was not recorded during the last census population in Chile (Sielfeld et al. 1997, Aguayo-Lobo et al. 1998, Oporto et al. 1999, Venegas et al. 2001, 2002) nor in regular visits to AMCP by one of us (JA) in the extensive humpback whales programme during the last six years.

Leucistic individuals have been reported frequently for Antarctic fur seals (Bonner 1958, Aguayo \& Torres 1967, Bonner 1968, Aguayo 1978, Cárdenas \& Yañez 1983, King 1983, Hofmeyr et al. 2005, De Bruyn et al. 2007), species that were severely reduced during the nineteenth and early twentieth century, with most populations becoming extinct (Bonner 1968). We compiled a list that includes overlooked and recent publications of white or leucistic otariids, and found that 


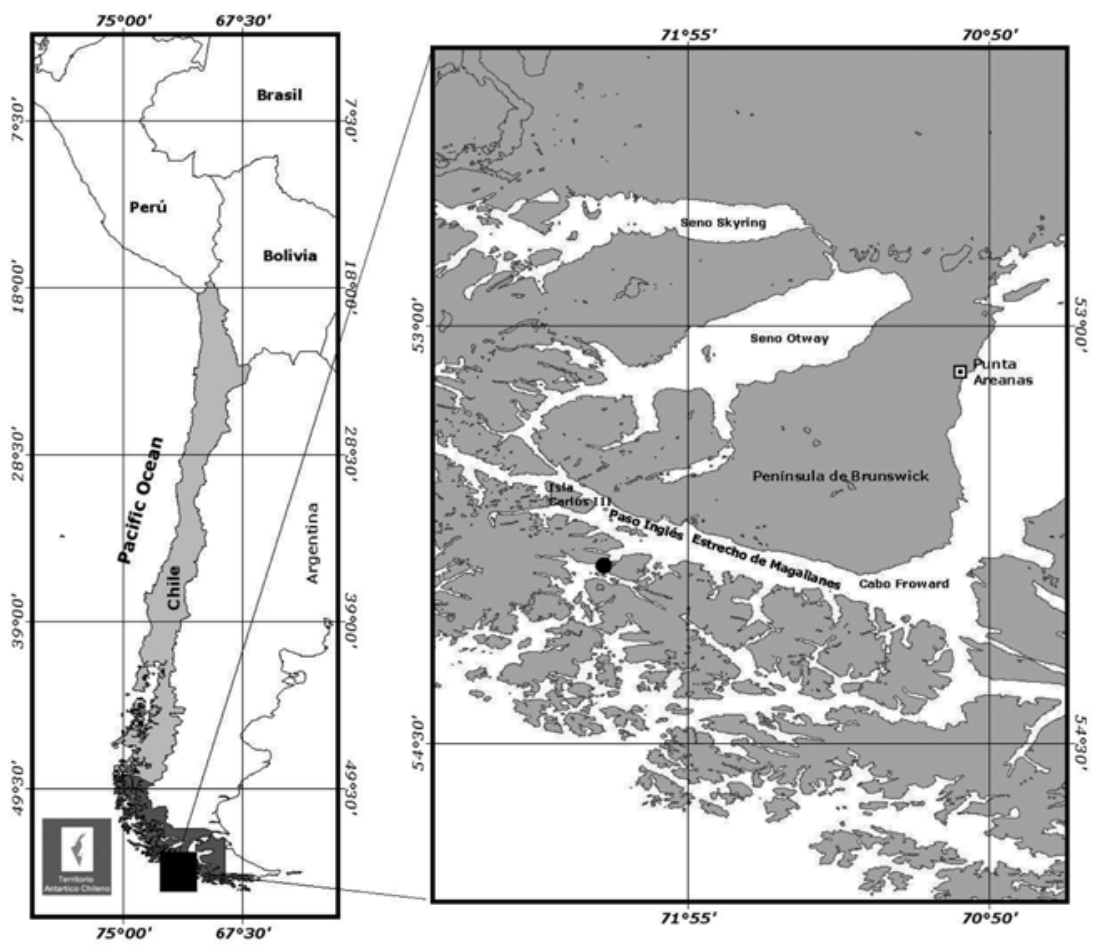

Figure 1

Location of leucistic individual of South American sea lion sighted on Southern Chile

Ubicación del individuo leucístico de lobo marino común avistado en el extremo austral de Chile

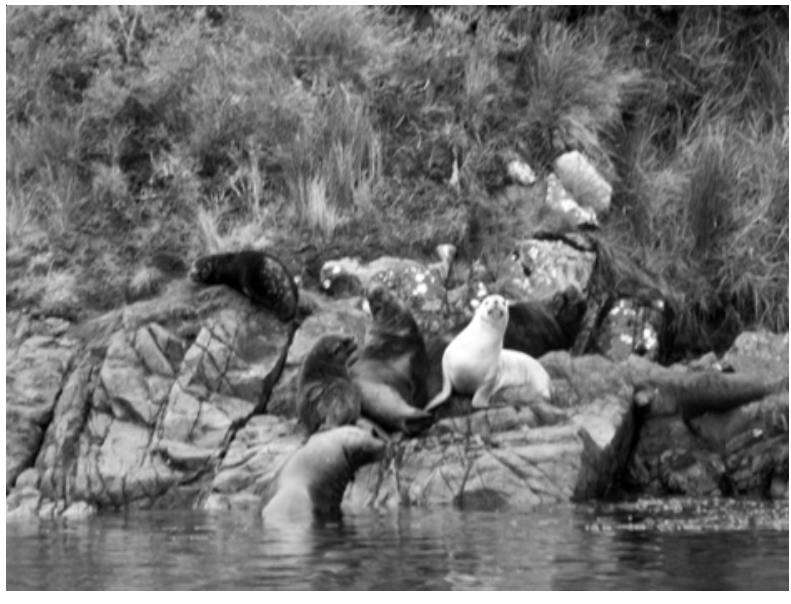

Figure 2

Leucistic South American sea lion photographed at Paso Shag, Chile

Ejemplar leucístico de lobo marino común fotografiado en el paso Shag, Chile these hypo-pigmented morphs have been observed in at least four other species: Northern fur seal, Steller's sea lion, California sea lion and South American sea lion (Table 1). The latter species is reported as albinistic with red eyes and white coat (López \& López 1984). In addition to this review, Hofmeyr et al. (2005) and De Bruyn et al. (2007) indicate the sighting of leucistic Antarctic fur seal at South Sandwich Islands from the report of Baker et al. (1964); however, no date of that atypical color is reported.

Other information cited as personal communication is available for three species of otariids, although the albinism condition is likely to be referred to leucistic animal. Bartholomew \& Hubbs (1952) wrote “....the long record of a moderate proportion of albinistic individual in this population (Zalophus californianus). This 'albinos' have been well known to the biologists who have visited the island from time to time during the past quarter century. Some were seen by us. Others are shown on a color photograph taken by Georges E. Lindsay in 1948. Lewis Wayne Walker estimates that the 'albinos' have constituted about ten per cent of the small population on 
Table 1

Published records of white or leucistic otariids

Registros publicados de otáridos con coloración anormal

\begin{tabular}{|c|c|c|c|}
\hline Date & $\mathrm{N}^{\circ}$ individuals & Location & Reference \\
\hline \multicolumn{4}{|c|}{ Antarctic fur seal (Arctocephalus gazella) } \\
\hline 1933 & 1 "pale golden" individual & Bird Island, South Georgia Islands & $\begin{array}{l}\text { Rayner \& Etheridge (1933) in } \\
\text { Bonner (1968) }\end{array}$ \\
\hline $1956-1957$ & $\begin{array}{l}2 \text { leucistic pups } \\
1 \text { leucistic adult female } \\
1 \text { leucistic juvenile male }\end{array}$ & $\begin{array}{l}\text { Johnson Cove, Bird Island, } \\
\text { South Georgia Islands }\end{array}$ & Bonner $(1958,1968)$ \\
\hline $1957-1958$ & 6 leucistic pups & Bird Island, South Georgia Islands & Bonner (1968) \\
\hline 1960 & 1 leucistic individual & $\begin{array}{l}\text { Michelsen Island, } \\
\text { South Orkney Islands }\end{array}$ & $\begin{array}{l}\text { Øristland (1960) in Bonner } \\
(1968)\end{array}$ \\
\hline $1960-1961$ & 1 leucistic adult male & South Georgia Islands & Bonner (1968) \\
\hline $1961-1962$ & $\begin{array}{l}9 \text { leucistic pups } \\
3 \text { leucistic adults male }\end{array}$ & South Georgia Islands & Bonner (1968) \\
\hline $1965-1966$ & 1 leucistic juvenile male & $\begin{array}{l}\text { Cabo Valentine, } \\
\text { Elephant Island, South Shetland } \\
\text { Islands }\end{array}$ & Aguayo \& Torres (1967) \\
\hline $1972-1973$ & 1 leucistic pup & Snow Island, South Shetland Islands & Aguayo (1978) \\
\hline $1972-1973$ & 1 leucistic juvenile male & Low Island, South Shetland Islands & Aguayo (1978) \\
\hline $1981-1982$ & 2 leucistic juveniles male & $\begin{array}{l}\text { Livingston Island, South Shetland } \\
\text { Islands }\end{array}$ & Cárdenas \& Yañez (1983) \\
\hline $1981-1982$ & 1 leucistic juvenile male & $\begin{array}{l}\text { King George Island, South Shetland } \\
\text { Islands }\end{array}$ & Cárdenas \& Yañez (1983) \\
\hline 1990 & 1 leucistic pup & Gold Bay, South Georgia Islands & Reeves et al. (1992) \\
\hline \multicolumn{4}{|c|}{ Steller's sea lion (Eumatopia jubatus) } \\
\hline Not available & $\begin{array}{l}\text { Occasional "albino" are } \\
\text { reported * }\end{array}$ & Not available & $\begin{array}{l}\text { Gentry (1970) in Loughlin et al. } \\
\text { (1987), King (1983) }\end{array}$ \\
\hline \multicolumn{4}{|c|}{ California sea lion (Zalophus californianus) } \\
\hline Not available & $\begin{array}{l}\text { "Albinistic" individuals are } \\
\text { reported * }\end{array}$ & Outer Islets, Guadalupe Island & Bartholomew \& Hubbs (1952) \\
\hline \multicolumn{4}{|c|}{ South American sea lion (Otaria flavescens) } \\
\hline 1979 & 1 albino pup ** & $\begin{array}{l}\text { Punta Norte, Península Valdés, } \\
\text { Argentina }\end{array}$ & López \& López (1984) \\
\hline
\end{tabular}

* The albinism condition is likely to be referred to leucistic animal.

** The authors reported red eyes and white coat.

each of his several visits during the past twenty years. He further states that William E. Clover, who rediscovered the fur seals on the island, and Dr. Harry Wegeforth, when President of the San Diego Zoological Society, and also Luis Camillo and others, often spoke of seeing albinos on the south side of Outer Islet repeatedly from 1926 to about 1935."
In subantarctic fur seal, 'albinism' (or presumably leucism) was reported by J.Y. Georges to Bried \& Haubreux (2000). For the South American sea lion, López \& López (1984) reported one albino sighted in Lobos Island, Uruguay by I. Ximénez, and one 'albinistic' pup at Faro Punta Norte during 1982 by M. Lewis, however, no more details of this presumably 'albinistic' morph is 
given. The sighting of this individual South American sea lion represents the first report known of a leucistic of this species in Chile.

Little is known about the cost associated with this hypo-pigmentation. Some authors suggest that these animals may be more susceptible to predation than normally pigmented conspecifics, reduced viability due to pathological traits such as sensory or nervous defects, anemia, low fertility, higher susceptibility to disease, poor vision, or that interactions with conspecifics can also be impaired. Moreover, an anomalously light coloration may also decrease heat absorption abilities for mammals that live in cold waters (Hain \& Leatherwood 1982, Jehl 1985, Fertl \& Rosel 2002). Despite this, some individuals can attain adult age and breeding status (e.g. Bonner 1968).

Although the interpretation of the biological significance (causes and effects) of atypical color patterns are uncertain, the subject is interesting because leucism may provide indirect evidence of underlying genetic variability, genetic change to variation in fitness-related traits and/or population structure. We encourage others to publish their observations so that a proper assessment of the ecological, physiological and genetics implications of this condition in otariids can be conducted in the future.

\section{Acknowledgments}

Thanks are given to the Director of the Fundación Centro de Estudios del Cuaternario (CEQUA) for the continuous support in the marine mammal survey. Thanks are also extended to 'Chonos' crew for the logistic support during the sailing, to Emma Newcombe for the revision of this manuscript, and the anonymous reviewers for their valuable comments and suggestions to improve this manuscript.

\section{Literature cited}

Aguayo A. 1978. The present status of the Antarctic fur seal Arctocephalus gazella, at South Shetland Islands. Polar Record 19(119): 167-176.

Aguayo A \& D Torres. 1967. Observación sobre mamíferos marinos durante la Vigésima Comisión Antártica Chilena. Primer censo de pinipedos en las Islas Shetland del sur. Revista de Biología Marina 13(1): 1-57.

Aguayo-Lobo A, H Díaz, J Yánez, F Palma \& M Sepúlveda. 1998. Censo poblacional del lobo marino común en el litoral de la V a la IX Regiones. Informe Final Proyecto Fondo de Investigación Pesquera 96-51: 1-214.

Baker PE, MW Holdgate, RE Longton, PJ Tilbrook, JF Tomblin, RW Vaughan \& CJC Wynne-Edwards. 1964. A survey of the South Sandwich Islands. Nature 203: 691693.
Bartholomew GA \& CL Hubbs. 1952. Winter population of pinnipeds about Guadalupe, San Benito, and Cedros Islands, Baja California. Journal of Mammalogy 33(2): 160171.

Bester MN, H de Clerq, GJG Hofmeyr \& PJ Nico de Bruyn. 2008. Leucistic southern elephant seal at Marion Island? Polar Biology 31: 255-257.

Bonner WN. 1958. Notes on the Southern Fur Seal in South Georgia. Proceedings of the Zoological Society of London 130(2): 241-252.

Bonner WN. 1964. Population increase in the fur seal Arctocephalus tropicalis gazella, at South Georgia. In: Carrick R, MW Holdgate \& J Prévost (eds). Biologie Antarctique: Proceedings of the First Symposium organized by SCAR 1962, pp. 433-443. Hermann, Paris.

Bonner WN. 1968. The Fur seal of South Georgia. British Antarctic Survey. Scientific Report 56: 1-81.

Bried J \& D Haubreux. 2000. An aberrantly pigmented southern elephant seal (Mirounga leonine) at Iles Kerguelen, Southern Indian Ocean. Marine Mammal Science 16(3): 681-684.

Cárdenas JC \& J Yáñez. 1983. Variaciones extremas de color del Lobo Fino Antártico, Arctocephalus gazella (Peters, 1875), en las islas Shetland del Sur, Chile. (Pinnipedia: Otariidae). Serie Científica INACH 30: 5-12.

De Bruyn PJN, PA Pistorius, CA Tosh \& MN Bester. 2007. Leucistic Antarctic fur seal Arctocephalus gazella at Marion Island. Polar Biology 30: 1355-1358.

Fertl D \& P Rosel. 2002. Albinism. In: Perrin WF, B Würsig \& JGM Thewissen (eds). Encyclopedia of Marine Mammals, pp. 16-18. Academic Press, San Diego.

Fertl D, LT Pusser \& JJ Long. 1999. First record of an albino bottlenose dolphin (Tursiops truncatus) in the Gulf of Mexico, with a review of anomalously white cetaceans. Marine Mammal Science 15(1): 227-234.

Fertl D, NB Barros, RA Rowlett, S Estes \& M Richlen. 2004. An update on anomalously white cetaceans, including the first account for the pantropical spotted dolphin (Stenella attenuata Graffmani). The Latin American Journal of Aquatic Mammals 3 (2): 163-166.

Hain JH \& S Leatherwood. 1982. Two sightings of white pilot whales, Globicephala melaena, and summarized records of anomalously white cetaceans. Journal of Mammalogy 63: 338-343.

Hofmeyr GL, MN Bester \& SP Kirkman. 2005. Leucistic Antarctic fur seals at Bouvetøya. Polar Biology 29: 77-79.

Jehl J. 1985. Leucism in eared grebes in western North America. The Condor 87: 439-441.

King J. 1983. Seals of the world, 240 pp. Coirnell University Press, Ithaca.

López JC \& D López. 1984. Sobre un caso de albinismo en el lobo marino de1 sur (Otaria flavescens Shaw, 1800) en Punta Norte, Península Valdés, Argentina. Actas Tercera 
Reunión Iberoamericana de Conservación y Zoología de Vertebrados (Buenos Aires, 1982). Revista del Museo Argentino de Ciencias Naturales Bernardino Rivadavia, Zoología XII (26): 255-257.

Loughlin TR, MA Perez \& LR Merrick. 1987. Eumetopias jubatus. Mammalians species Account 283: 1-7.

Oporto J, L Brieva, R Navarro \& A Turner. 1999. Cuantificación poblacional de lobos marinos en el litoral de la X y XI Regiones. Informe Final Proyecto Fondo de Investigación Pesquera 97-44: 1-237.

Reeves RR, BS Stewart \& S Leatherwood. 1992. The Sierra Club handbook of seals and sirenians. 359 pp. Sierra Club Books, San Francisco.

Scheffer VB. 1962. Pelage and surface topography of the northern fur seal. US Department Interior Nature American Fauna 64: 1-92.
Sielfeld W, C Guerra, LR Durán, E Acuña, AAguayo-Lobo, M Sepúlveda, F Palma, A Malinarich, G Cerda, A Bolvarán, R Grau, X Veloso, Y Guerra, M Vargas, N Amado, R Peredo \& J Galaz. 1997. Monitoreo de la pesquería y censo del lobo marino común en el litoral de la I-IV Regiones. Informe Final Proyecto Fondo de Investigación Pesquera 95-28: 1-105 pp.

Venegas C, J Gibbons, A Aguayo, W Sielfeld, J Acevedo, N Amado, J Capella, G Guzmán \& C Valenzuela. 2001. Cuantificación poblacional de lobos marinos en la XII Región. Informe Final Proyecto Fondo de Investigación Pesquera 200022: 1-92.

Venegas C, J Gibbons, A Aguayo, W Sielfeld, J Acevedo, N Amado, J Capella, G Guzmán \& C Valenzuela. 2002. Distribución y abundancia de lobos marinos (Pinnipedia: Otariidae) en la Región de Magallanes, Chile. Anales del Instituto de la Patagonia, Serie Ciencias Naturales 30: 67-82.

Recibido el 2 de enero de 2008 y aceptado el 6 de marzo de 2008 